\title{
Living in Subalterinity: The Voiceless Others in Nadine Gordimer's Selected Short Stories
}

\author{
Morteza Babaei ${ }^{1}$, Fatemeh Pourjafari ${ }^{2}$
}

\author{
${ }^{1}$ M.A in English Literature \\ ${ }^{2}$ Department of English Language and Literature, Kerman Branch, Islamic Azad University, Kerman, Iran
}

Received: 25 Sep 2021; Received in revised form: 30 Oct 2021; Accepted: 06 Nov 2021; Available online: 13 Nov 2021

(C)2021 The Author(s). Published by Infogain Publication. This is an open access article under the CC BY license

(https://creativecommons.org/licenses/by/4.0/).

\begin{abstract}
This paper discusses some selected short stories of Nadine Gordimer in the light of the Postcolonial theory of Gayatri Chakravorty Spivak. Gordimer was one of the leading figures in world literature against apartheid, and most of the events in her stories, take place in the context of the black community. As the most critical aspect of her short stories is the description of the lower classes of society in African communities, the postcolonial approach has been chosen to study her works. Spivak describes colonized people as others or inferiors who usually are known as subalterns. Women have a significant role in her theory, and she believes that women in colonial discourse are double subalterns. According to what is expected, it would be seen that in Gordimer's short stories, the subalterns have no voice, and their identity is affected by the colonizer's culture, language, and behavior.
\end{abstract}

Keywords_Gordimer, Postcolonialism, Spivak, Subaltern.

\section{INTRODUCTION}

Nadine Gordimer was born on 20 November 1923 in Springs, a small mining town near Johannesburg in South Africa. Her parents were Jewish immigrants. Her father came from Lithuania and her mother from England. She began to write when she was only nine, and her first short story was published at the age of fifteen in a South African magazine. Face to Face, her first collection of short stories, was published in 1949 and, The Lying Days, her first novel, was published in 1953. She published 15 novels and some collections of short stories, including more than 200 short stories and a few works of literary criticism. Furthermore, many articles, speeches, and lectures on different subjects are another part of her works. Some of her books had been banned in her native country, under the apartheid regime.

She is known as a woman "who through her magnificent epic writing has - in the words of Alfred Nobel - been of very great benefit to humanity" (The Nobel Prize, 1991). She won many significant awards, including the Booker Prize in 1974 for The
Conservationist and The Nobel Prize in 1991 for My Son's Story. She was active in the anti-apartheid movement. She joined the African National Congress when the organization was banned and quickly became active in South African politics. She also was close friends with Nelson Mandela's defense attorneys during his 1962 trial. When Mandela was released from prison in 1990, she was one of the first people he wanted to see. She was also active in HIV/AIDS movements. She died on 13 July 2014.

Gordimer's writings deal with moral and racial issues, particularly the consequences of apartheid in South Africa. Her characters are ordinary people, constantly questioning power relations and truth and revealing moral ambiguities and choices. Gordimer writes with intense immediacy about the extremely complicated personal and social relationships in her environment. The identity she made for her characters is based on what she saw in her native country. Gordimer takes the question of the justification of the privileges of white people - even benevolent white people - to its extreme. 
As Gordimer's works relate to anti-apartheid activities and most of her stories are about blacks and their relations to whites, the Postcolonial view can be applied to her works very well. Identity is the common subject in Postcolonial criticism and most of Gordimer's short stories. This research will focus on some of her short stories to find the subject of identity within a Postcolonial view. "Six Feet of the Country," "Which New Era Would That Be," "Town and Country Lovers," "Livingstone's Companions" are selected from her Life Times: Stories and "Mission Statement," and "Visiting George" from her Loot and Other Stories.

\section{SUBALTERNITY}

Gayatri Chakravorty Spivak is a leading figure in Postcolonial studies, the academic field that examines the impact of colonial control on former colonies. She was one of the pioneers of using Postcolonial approaches to analyze literary texts. Prior to her work, "the literature from nations newly independent of their colonial masters was widely considered the literature of the former ruling country and its former colonies; Britain's numerous former colonies was termed 'Commonwealth Literature,' for example. This is a problematic classification, as it gives a Eurocentric view of English literary studies: it upholds a Center-Periphery model of culture, in which the culture of the colonizing country is taken to be dominant and superior" (Riach, 2017, pp. 22-23).

The term 'subaltern,' “drawn from Antonio Gramsci's writings, refers to subordination in terms of class, caste, gender, race, language, and culture and was used to signify the centrality of dominant/dominated relationships in history" (Prakash, 1994, p. 1477). Gramsci adopted the term subaltern as "'of inferior rank,' which refers to those groups in society which are subject to the hegemony of the ruling classes" (Manggong, 2019, p. 136). It is important to note that "Europe or the West in Subaltern Studies refers to an imaginary though powerful entity created by a historical process that authorized it as the home of Reason, Progress, and Modernity" (Prakash, 1994, p. 1486).

Subaltern refers to the people known as the lower class and has no voice in society. Spivak tries to say that the subaltern voice should be heard. She talks mainly about the status of women in Third World, where women are victims of their societies, and even they have no voice in their own houses. In order to be heard, the subaltern must adopt Western thought, reasoning, and language. Because of this, Spivak argues that the subalterns can never express their reasoning, forms of knowledge, or logic; they must instead form their knowledge to Western ways of knowing. She wants to give voice to the subalterns who cannot speak or who are silent.

As the status of women is very important for Postcolonial critics, especially for Spivak, it should be said that the critical subject position disentangled by Spivak is that of the female subaltern and the practice of Sati or widow immolation. In Sati, the widow is burnt to death on her husband's funeral pyre: "she is defined solely through the identity of her husband, and is therefore

considered to have no identity worth continuing after his death" (Lane, 2006, p. 247).

The critical goal of Postcolonial theorists is clearing space for multiple voices. This is especially true of those voices that have been previously silenced by dominant ideologies - subalterns. In Postcolonialism and related fields, subaltern refers to socially, politically, and geographically outside the hegemonic power structure. Spivak's main contribution to Postcolonial theory came with her specific definition of the term subaltern: "Spivak's subaltern studies reveal how female subjects are silenced by the dialogue between the male-dominated West and the male-dominated East, offering little hope for the subaltern women's voice to rise amidst the global social institutions that oppress her" (Guerin et al., 2011, p. 364).

'Can the Subaltern Speak?' marked a pivotal moment in subaltern studies and Postcolonial theory. In this essay, Spivak "views the fate of the subaltern subject and how the politics of representation can mar it. Since only the privileged people in the society can represent, effective representation of the subaltern subject can be futile. This will always keep the subaltern in the terrain of margin, the silent center, the center of voicelessness" (Binebai, 2015, p. 208). She believes that when the subaltern speaks, it is not subaltern anymore, so subalterns are marginalized people who have no voice, and they are people who find it difficult to speak. In her view, they should be inventors and masters of their voices. Moreover, it can be said that where there is no voice, there is no identity.

Spivak concludes that "the subaltern cannot speak" (1994, p. 104). This is because "they are always spoken for by those in positions of power, and are never able to represent themselves. Further, if they do speak, they are not heard" (Riach, 2017, p. 12). Spivak understands speaking as a transaction between a listener and a speaker: "When you say cannot speak, it means that if speaking involves speaking and listening, this possibility of response, responsibility, does not exist in the subaltern's sphere." (De Kock, 1992, p. 46). If subalterns want to be successful, their speech must indicate its message, but in Spivak's view, subaltern speech cannot attain this goal. 


\section{THE SUBALTERNS IN GORDIMER'S SHORT STORIES}

As already mentioned, the term 'subaltern' refers to those people of inferior status or rank. In other words, it means subordinate people, hence, of rank, power, authority, or action. Subaltern studies analyze the binary relationship of the subaltern and ruling classes and thus study the interaction of dominance and subordination in colonial systems.

For Spivak, the term 'subaltern' is valuable 'because it is flexible; it can accommodate social identities and struggles (such as women and the colonized) that do not fall under the reductive terms of strict class-analysis" (Morton, 2004, p. 45). As women's role in subalternity is so significant, this section is divided into non-feminine and feminine subalterns.

\subsection{Blacks as Subalterns}

"Six Feet of the Country" is a short story by Nadine Gordimer, which represents the blacks as subalterns who have no voice in their society, and if they want their voice to be heard, they have to ask the whites. The story sets on a farm near Johannesburg. After a black man is found dead on their property, the white couple that owns the farm finds that their attempts to help their employees bury the body are at odds with the bureaucratic apartheid system. Lerice and her husband are awoken one night by one of their farmworkers, who informs them that a stranger, who is close to death, has been found on their property. The couple quickly discovers that the stranger is Petrus' brother, one of their farm boys, and has traveled illegally from Rhodesia. Rhodesia people are shown very well as the real subalterns in this story:

Rhodesian natives are barred from entering the Union unless they have a permit; the young man was illegal. No doubt our boys had managed the whole thing successfully several times before; a number of relatives must have walked the seven or eight hundred miles from poverty to the paradise of zoot suits, police raids, and black slum townships that is their Egoli, City of Gold - the Bantu name for Johannesburg. (Gordimer, 2011, p. 28)

After the stranger dies, Lerice and her husband explain to Petrus that his brother's corpse must be taken away for a post-mortem so that the health authorities can determine the cause of death. For Petrus to give his brother a traditional funeral, he must pay the government 20 pounds to return the body. Believing that a white man would be better able to solve the problem, Petrus and the other black farm workers look to Lerice and her husband to help them retrieve the correct body. As they are subalterns, their voices cannot be heard in society. They need someone else, a white, to be their voice and ask the authorities to fetch the corpse back: "Will the baas please ask them when we must come?" (2011, p. 29).

Petrus thinks that as his baas is a white, he can do anything if he wants: "He just kept on looking at me, out of his knowledge that white men have everything, can do anything; if they don't, it is because they won't" (2011, p. 30). At the funeral, it is discovered that the authorities have returned the wrong body. Lerice's husband struggles with government bureaucracy but cannot confirm the whereabouts of the body or get a refund on the 20 pounds paid by Petrus.

"Which New Era Would That Be" is a vignette of a visit made under the apartheid regime by two white liberals, Alister Halford and Jennifer Tetzel, to the Johannesburg printing shop of Jake Alexander, who is of a mixed-race background. The story is about hypocrisy, exploitation, and various stresses shown on the typical blacks by the power maniac whites. It represents for Gordimer the mark of her transition to adopting the black standpoint on social attitude. She professionally portrays the blacks as subalterns whose voices are never heard in society. In the story, the host, Jake Alexander, the halfwhite, and a group of blacks are visited by a young liberal white lady, Jennifer, and a white friend called Alister. When Jake sees the white lady, she reminds him of some happenings in his childhood, when parson knew themselves equal with them:

He thought that that was even worse than the parsons who persisted in regarding you as their equal. The parsons had had ten years at school and seven years at a university and theological school; you had carried sacks of vegetables from the market to white people's cars from the time you were eight years old until you were apprenticed to a printer, and your first woman, like your mother, had been a servant, whom you had visited in a backyard room, and your first gulp of whisky, like many of your other pleasures, had been stolen while a white man was not looking. Yet the excellent parson insisted that your picture of life was exactly the same as his own: you felt as he did. (2011, p. 55)

For him, this woman was someone like that parsons, even worse than them, because she knew herself as equal as them:

But these women - oh, Christ! - these women felt as you did. They were sure of it. They thought they understood the humiliation of the pureblooded black 
African walking the streets only by the permission of a pass written out by a white person, and the guilt and swagger of the colored man light-faced enough to slink, fugitive from his own skin, into the preserves - the cinemas, bars, libraries that were marked EUROPEANS ONLY. Yes, breathless with stout sensitivity, they insisted on walking the whole teeter-totter of the color line. There was no escaping their understanding. They even insisted on feeling the resentment you must feel at their identifying themselves with your feelings . . (2011, pp. 55-56)

After getting introduced to each other, the group starts talking about the social and political climate of South Africa. As the story progresses, one is given a clear picture of the hostility between the world of oppressors and the oppressed. One is also told about the effects of racial suppression on the psyche and the emotional reactions of the blacks. Gradually one comes to know that the so-called liberal, intellectual, dark-haired Jennifer refuses to believe an anecdote about a black being the victim of whites' hypocrisy. Then Maxie, a black friend of the host, says about the refusal of a white host to share a meal with him, to whom the white host offered a drink:

'Then, just about lunchtime, we came to this place I wanted to tell you about. Nice chap, the manager. Never blinked an eye at me, called me Mister. And after we'd talked, he said to George, "Why not come home with me for lunch?" So of course George said, "Thanks, but I'm with my friend here." "Oh, that's OK," said the chap. "Bring him along." Well, we go along to this house, and the chap disappears into the kitchen, and then he comes back and we sit in the lounge and have a beer, and then the servant comes along and says lunch is ready. Just as we're walking into the dining room, the chap takes me by the arm and says, "I've had your lunch laid on a table on the stoep. You'll find it's all perfectly clean and nice, just what we're having ourselves." (2011, pp. 62-63)

Jennifer couldn't believe it "as if this were a problem to be solved psychologically" (2011, p. 63). She begins to internalize the pressures of apartheid by saying that Maxie doesn't have "an African accent, as some Africans have, even if they get rid of the Bantu thing" (2011, p. 63). Then Maxie quotes another incident where he is mistaken to be a European, over the phone, by a white lady and how the same lady gets terrified on seeing after a week:

'Anyway, I'd had to phone a certain firm several times,' Maxie went on, 'and I'd got to know the voice of the girl at the other end, and she'd got to know mine. As a matter of fact, she must have liked the sound of me, because she was getting very friendly. We fooled about a bit, exchanged first names, like a couple of kids - hers was Peggy - and she said, eventually, "Aren't you ever going to come to the office yourself?"' .... 'So I told her I'd be in next day, about four. (2011, p. 63)

In the next day's appointment, when the girl understands that the one who had an appointment with her was a black man, she had a different reaction:

... 'She almost dropped my hand, and then she pumped it like a mad thing, and her neck and ears went so red I thought she'd burn up. Honestly, her ears were absolutely shining. She tried to pretend she'd known all along, but I could see she was terrified someone would come from the inner office and see her shaking hands with a native. So I took pity on her and went away. Didn't even stay for my appointment with her boss. When I went back to keep the postponed appointment the next week, we pretended we'd never met.' (2011, p. 64)

She did not expect the voice on the phone to belong to a black man. For her, the blacks were terrifying, and she saw them as inferiors who had no value to her. Finally, Jennifer's answer, "it's hard to be punished for not being black" (2011, p. 64), shows a considerable amount of bitter irony. Gordimer ends the story with a positive note as she has the feeling that a time will come when both blacks and whites will forget the social division and begin to live together. Gordimer ends her description of their exchange by writing, "The small perfectly made man crossed his arms and smiled, watching her go. Maxie had no price" (2011, p. 65).

"Town and Country Lovers" is a two-part story about interracial lovers who suffer the consequences of breaking the rules forbidding such relationships that significantly indicate the subalternity in non-Western societies. In the first story, 'Town Lovers,' solitary geologist Dr. von Leinsdorf meets a young, colored, mixed-race African girl who is a cashier at the grocery store across the street from his apartment. When the store is out of the razors he likes, she makes an effort to get some for him. He asks her to bring them to his apartment, and she soon begins to deliver his groceries for him a few times a week. Before long, the two become sexually involved. He enjoys her company and her sexual availability to him, and he tries to help her 
by teaching her to swim, type, and improve her grammar. Ones, when she went to that apartment,

She was stopped by the caretaker and asked what she wanted in the building? Heavy with the bona fides of groceries clutched to her body, she said she was working at number 718 , on the seventh floor. The caretaker did not tell her not to use the whites' lift; after all, she was not black; her family was very light-skinned. (2011, p. 249)

The discrimination between whites and blacks is undeniable in this part. The blacks shouldn't use even the lift that is for whites, and this is an example of subalternity. After that, the cashier tells the other people in the building and her mother that she works for Dr. von Leinsdorf. Still, the police arrive one day to search the apartment for the girl. They have been watching and know that she is there. There is a law that forbids interracial sexual relationships, and when the police discover the cashier hiding in a closet, she and Dr. von Leinsdorf are arrested. In jail,

Dr Franz-Josef von Leinsdorf, described as the grandson of a baroness, a cultured man engaged in international mineralogical research, said he accepted social distinctions between people but didn't think they should be legally imposed. 'Even in my own country it's difficult for a person from a higher class to marry one from a lower class.' (2011, pp. 254-255)

Dr. von Leinsdorf secures their release from jail through his attorney, and when no evidence of sexual relations is discovered, the charges are dropped. The cashier tells the newspapers that she is sorry for the pain she has caused her mother, and the mother says that she will never let her daughter work for a white man again. The racial laws forbid blacks, as subalterns, to have relations with whites.

Similar to the first part, the second part, or the 'Country Lovers' part, is a story of a white farmer's son who falls in love with the daughter of an African worker. As children, the two play together, but when they grow up, the situation is different:

The farm children play together when they are small; but once the white children go away to school they soon don't play together any more, even in the holidays. Although most of the black children get some sort of schooling, they drop every year further behind the grades passed by the white children; ...... This usefully coincides with the age of twelve or thirteen; so that by the time early adolescence is reached, the black children are making, along with the bodily changes common to all, an easy transition to adult forms of address, beginning to call their old playmates missus and baasie - little master. (2011, p. 256)

In fact, the blacks try subalternity from the time they are teenagers. They learn to be subaltern by prohibiting to play with whites and moreover by the difference in the type of education they receive. They learn to call the whites missus and baas from their childhood and accept to be subaltern.

As they grow, they have romantic fantasies of each other. They start engaging in sexual relations, which leads to pregnancy. The pregnancy, however, does not show until the African girl is betrothed to a young and kind African man. When she gives birth, it becomes clear that the baby is not her husband's, but it is not something odd among the people: "Two months after her marriage to Njabulo, she gave birth to a daughter. There was no disgrace in that; among her people, it is customary for a young man to make sure, before marriage, that the chosen girl is not barren, and Njabulo had made love to her then" (2011, p. 259).

In such a society, women are viewed as worthless creatures and men have the right to make love with them before marriage to make sure that they are not barren. Nonetheless, the husband agrees to raise the light-skinned baby as his own. The white farmer's son hears of news of his child and driven by paranoia, draws up a plan to poison the baby so no one will know he is the father. His plan succeeds, but he is arrested and later set free after the African girl claims she is not sure whether he was the one who poisoned their child.

\subsection{Women as Double Subalterns}

Spivak believes that in Postcolonial societies, women's situation is even worse than men. In A Critique of Postcolonial Reason, she talks about the sexual difference in Postcolonial societies and states that "Within the effaced itinerary of the subaltern subject, the track of sexual difference is doubly effaced. The question is not of female participation in the insurgency, or the ground rules of the sexual division of labor, for both of which there is 'evidence'. It is, rather, that, both as the object of colonial historiography and as subject of insurgency, the ideological construction of gender keeps the male dominant. If in the context of colonial production, the subaltern has no history and cannot speak, the subaltern as female is even more deeply in the shadow" (1999, p. 274). 
A good example of subaltern women in Nadine Gordimer's short stories can be found in "Mission Statement", where a white woman from a foreign country wants to marry a Black in high position from South Africa as his second wife, and one of her colleagues alerts her of the status of women in the country:

-I'm going to be frank with you. I'm sure he's become very attached to you, but there's another aspect to this-proposal-his wife is a simple woman who takes care of the kids, there's a boy of about ten as well as the grown ones making their way around the world-she shops for the official residence she's so proud of, watches TV; and has nothing to say to him, he obviously can't discuss his work, inside politics and problems of government, not with her. ... he needs a companion on his own wave-length at his stage of life and clearly that's what he's found these past months in you. He's seen how astutely you hold your own at meetings, how you can have an-informed-exchange with all kinds of people! That's how he thinks of a second wife. Not a handy bedmate. (Gordimer, 2003, p. 44)

Then he continuous talking about developing countries where:

women may be beautiful and desirable but social disadvantages, pressures of all kinds-you know them-have deprived them of education, worldliness, if you like. Even now, there aren't enough women here on the level of the Minister of Welfare, that great gal, one of the liveliest MPs, never mind the males ... And there's something else-strict confidence! — could relate to Gladwell's decision (2003, p. 44).

As can be seen, women in these societies have no identity of themselves and are not allowed to be educated. Here, the wife is described as a subaltern who takes care of the kids and has nothing to say to her husband, especially his work.

Spivak discusses how Western scholarship always disguises third world peoples or those from the developing countries, and shows why subaltern women are doubly marginalized, first as the colonized, then again as women. She focuses on epistemic violence or violence inflicted through thought, speech, and writing rather than actual physical harm. For Spivak, "a good example of epistemic violence is when accounts of history leave out subalterns. When oppressed peoples are not allowed to speak for themselves or have their contributions recognized, they are erased from their place in the world. This is especially common for subaltern women" (Riach, 2017, p. 11).
"Visiting George", another short story by Nadine Gordimer which is about a visit to the Kensington apartment of a politically involved South African exile, George whom writer and her friend hadn't seen in a while, and the writer's speculation on George's absent wife in the course of a memorable afternoon there, is another example of feminine subalternity that shows the women as double subalterns, when the author talks about the ignored role of woman in political events by man: "So that's how it always really was. He made the opinions, created the 'we', set the itinerary of the political quests. So it didn'tdoesn't matter whether she's mentioned or not, does it. You are, I am, because we have each our opinions. We exist" (Gordimer, 2003, p. 48).

Another example of feminine subalternity is shown in "Livingstone's Companions," where "The women of that country had been on sale to white men for a number of generations" (2011, p. 172). And this indicates the low status of black women in an African society where women were sold to white men for generations. They are on sale not even because they are subaltern, but also because they are women, or it is better to say double subalterns.

Spivak also saw the history of colonialism as a history of oppression and exploitation of women, especially the non-European underprivileged, and this, of course, applied to Middle Eastern women, as these women were "victimized on both sides of the colonial divide that is in the British colonial archives as well as in the postcolonial nationalist annals" (Sakhkhane, as cited in Abdelfattah, 2021 , p. 2). Furthermore, one of the main concerns in 'Can the Subaltern Speak?' is the doubly silenced position of subaltern women. It is important to remember that colonial and patriarchal forms of oppression are not separated from Spivak. They enter into legal, economic, scholarly, and other systems of power to produce a global society that is distinctive and authoritarian to its core. The colonial and patriarchal practices work together to silence subaltern women's voices.

\section{CONCLUSION}

As it can be seen, many of Gordimer's short stories are based on conflicts between blacks and whites in South Africa or other African countries. Most of the blacks are known as inferiors or others who have no voice in their society. Moreover, some of her characters are refugees who have taken refuge in other countries. Based on Spivak's Postcolonial theories, subalterns are those people who have no voice in society and usually are seen as inferiors or others: blacks, women, workers, peasants, and minorities. In Gordimer's short stories, blacks are pictured as subalterns who have no voice and are sometimes 
forbidden from their primary rights. In addition, women who usually known as double subalterns, have a significant role in Gordimer's fiction.

\section{REFERENCES}

[1] Abdelfattah, H. A. M. (2021). When the subaltern Speaks: Solo Narrative Performance in Heather Raffo's Nine Parts of Desire and Issam El-Yousfi's Tears with Alcohol. Interventions, $1-14$. https://doi.org/10.1080/1369801x.2020.1863835

[2] Binebai, B. (2015). Voice Construction in the Postcolonial Text: Spivakian Subaltern Theory in Nigerian Drama. African Research Review, 9(4), 206. https://doi.org/10.4314/afrrev.v9i4.16

[3] De Kock, L. (1992). Interview with Gayatri Chakravorty Spivak: New Nation Writers Conference in South Africa. ARIEL: A Review of International English Literature.

[4] Gordimer, N. (2003). Loot and other stories. New York: Farrar.

[5] Gordimer, N. (2011). Life times: Stories. New York: Penguin.

[6] Guerin, W. L., Labor, E., Morgan, L., Reesman, J. C., Willingham, J. R., \& Willingham, J. (1998). A Handbook of Critical Approaches to Literature (4th ed.). Oxford University Press.

[7] Lane, R. J. (2006). Fifty Key Literary Theorists (Routledge Key Guides) (1st ed.). Routledge.

[8] Manggong, L. (2019). Subaltern Voice and Marginal Moral Lessons in Suniti Namjoshi's Feminist Fables. Fabula, 60(1-2), 132-144. https://doi.org/10.1515/fabula-20190009.

[9] Morton, S. (2004). Gayatri Chakravorty Spivak. London \& New York: Routledge.

[10] Prakash, G. (1994). Subaltern Studies as Postcolonial Criticism. The American Historical Review, 99(5), 1475. https://doi.org/10.2307/2168385.

[11] Riach, G. (2017). An Analysis of Gayatri Chakravorty Spivak's Can the Subaltern Speak? (The Macat Library) (1st ed.). Macat Library.

[12] Spivak, G. C. (1994). Can the subaltern speak? In P. Williams and L. Chrisman (Ed.). Colonial Discourse and Postcolonial Theory: A Reader. (pp. 66-111). New York: Columbia University Press.

[13] Spivak, G. C. (1999). A Critique of Postcolonial Reason: Toward a History of the Vanishing Present. London: Harvard UP.

[14] The Nobel Prize in Literature. (1991). NobelPrize.org. Nobel Media AB 2020. Fri. 11 December 2020. https://www.nobelprize.org/prizes/literature/1991/summary/. 